\title{
The Initiators of Our Everyday Life - Relationship between Coffee and Instagram
}

\author{
Csilla CSÁKI \\ Corvinus University from Budapest \\ Budapest, Hungary \\ e-mail: cscsilla0811@gmail.com
}

\begin{abstract}
In this study, I would like to understand the background of sharing coffee online and get to know why it encourages young people to post their coffee. I analyse the two popular parts of our everyday lives, coffee and Instagram, and their connection points, which are coffee posts as communication tools and their posting and content sharing itself as a form of communication. In my theoretical background, I reflect on the process of coffee becoming a consumer product, the relationships between cafés and the public, and I reflect on the features of Instagram that captivate young people and enable online social rites. Regarding the question of presence, I am looking for the answer to the peculiarities of the relationship between online and offline, the dissonance caused by the simultaneous appearance on the two stages. The aim of the paper is to compare the traditional and the online characteristics of the coffee community and to interpret it as a rite. Based on the theoretical background of digital ethnography, using participatory observation and photomontage techniques, I explore attitudes and motivations among the Generation Z young people in Târgu-Mureş in terms of this activity. These two evocative methods, further interpreting the visuals of Instagram, allow interpretation not only from an aesthetic point of view but also in terms of the analysis of their symbol system, background, and motivations. In my interpretations, the acceptance of manipulation, the attitude of reality, the social characteristics of online coffee communities, the relationships between Instagram visuality and Generation Z media consumption needs, compensation practices that use coffee posts as an excuse and provide insight into the self-reflexive process of coffee post backgrounds are explicated. In my final conclusions, I outline the system of likeability for coffee posts as a feature of competitive, community photography. I refer to the sharing of coffee online as new contexts of parasocial relations, and I also reflect on coffee posts as a self-branding opportunity that can be used as a tool for self-expression.
\end{abstract}

Keywords: online/real presence, community, rite, social publicity, compensatory practice, consumer behaviour, snapshot culture, Instagram and identity 


\section{Introduction}

Examining the relationship between coffee and Instagram, I would like to understand and interpret the social practice entrenched in the online space, which shapes the everyday lives of contemporary consumer society, especially young adult's lives, almost unnoticed. There are few such widespread actions that define our daily routine that are as connected to our daily activities as posting coffee (making it available online). The social group that is involved in this topic is made up of the Internet users. It is produced and consumed by many people, whether they compose the image themselves or not. What do I mean by consuming coffee posts? As we browse, we do not only find or encounter information directly on the Internet based on the search terms we enter, but we also see a lot of seemingly incidental information that we do not even perceive at the moment, including Instagram posts about coffee. My research reflects on the motivation behind coffee posts, the attitudes associated with it, and the identityexpressing aspect influencing representations, which has become describable through a self-reflexive method.

\section{The Origin and Role of Coffee Consumption in Modern Societies}

Coffee can be considered a consumer good if we focus on how it is grown and sold. In my research paper, I discuss the origin of coffee only tangentially because I examine it more as a symbol. Nevertheless, the historical and social significance of coffee cannot be ignored because the spread of coffee did not start today. For us, coffee is part of our everyday lives; however, this has not always been the case even though it is hard to imagine today that there used to be a world without coffee. Until the mid-fifteenth century, coffee was completely unknown.

Coffee consumption first became established and incorporated into the culture among the peoples of the Red Sea region and then spread worldwide during the Age of Discovery. Coffee then became one of the great success stories of changing consumer habits, quickly becoming popular and a consumer product that transformed the early modern world. Although attitudes towards it were controversial in all societies at the beginning of its appearance, it soon found its place among more traditional beverages, such as beer, wine, water, and juices (see Cowan, 2005), so much that we can now easily talk about coffee culture and even coffee cultures. ${ }^{1}$ Coffee consumption is universal in its own way. Every nation drinks coffee, and, as Williams Harrison Ukers writes, it has become a basic human

1 More on the history of coffee and its social historical phenomenon: Jolliffe, Lee, 2010; Varga, V.-Dúll, Andrea, 2001; Kleidas, M.-Jolliffe, L., 2010; Gondola, A., 2015. 
need. This efficiency enhancer that complements human energy, according to Ukers, has become adored for two reasons: its efficiency enhancement and its pleasurable, experiential look (Ukers, 1922). Visual experience is associated with its popularity, and even with an experience that was once composed for their microenvironment and today for the entire global village, but specifically for the coffee community with the help of the World Wide Web.

\section{The Relationship between the Public and Cafés}

In the coffee community of the 1700s, the communicative event in the cafe was the expression of: identity, the social life corresponding to the rank, and interpersonal communication. According to Gábor Gyáni, "[...] Within the framework of the public space that differentiates during the separation of the private and public spheres, the café is at most a sphere of the semi-public. If the street, with its 'democratism' and its unrestricted accessibility to all, provides the fullness of a neutral public, a café-separated public space that separates the crowd and attracts socially filtered guests is a transition between privacy and metropolitan mass life” (Gyáni, 1996). How does this manifest itself in today's social media? Does Instagram mean a semi- or a fully democratized public space?

\section{Online Communities}

What does the online community mean? One of the earliest definitions originates from 1993, given by Rheingold, who states that virtual communities are social congregations that appear on the Internet when enough people have open discussions with the right human feelings and form a network of personal relationships in cyberspace (Rheingold, 1993). With the advent of social media, the emergence of online groups has accelerated, and their numbers have jumped by orders of magnitude. These groups are organized and articulated along different themes and motivations, but some of their characteristics, such as the way they are organized, the development and functioning of communication and hierarchy within the group, are very similar. The similarities between the groups organized in the social media were systematized by Adrienn Ujhelyi. According to the author, based on empirical studies, it can be clearly stated that fundamental similarities, norms, and roles are formed in the same way, the same group dynamic processes take place, a common language, group structure develops, and conformity or group polarization occurs under appropriate conditions (Ujhelyi, 2013: 3). In this case, the mapping of coffee communities can show similar characteristics both online and in real space. 


\section{Sharing the Act of Drinking Coffee Online as a Rite}

Just as in the coffee house communities of the 1700s, we can find in today's online communities the practice of coffee making, talking about coffee, making narratives and then pictorial representations about coffee. Examining from an anthropological view the reason for coffee posts, Victor Turner's rite theory can help to form a coherent picture of the cause-and-effect relationships. According to Turner, the rites that appear in folk cultures are the basis of social cohesion: these symbolic practices are able to ensure the survival of a given society even in times of crisis (Turner, 1969). So, if we look at coffee consumption as a rite, then we can understand why a "coffee community" can be formed even online. Therefore, if we interpreted making coffee and posting it as a rite, we must say that in the practice of posts about coffee we can identify an action that promotes a very strong group identity. We can even say that within a given age-group/ community, these posts (content) create strong cues and meanings that are easily decoded and confirmed by the participants. In Durkheim's work, we can read that at the base of every rite there is a separation of sacred and profane elements, and there is no social rite in which elements of religious origin cannot be found (Durkheim, 2002). Coffee used to be a status symbol. Coffee was consumed only by the élite, but today, thanks to its widespread use, it has changed significantly. In this new environment, coffee is a source of prosperity, happiness, young adult status, and so on. It has become a symbol that hashtags make visible in the online space. These image compositions also contain a series of hidden symbols such as watch, book, ring, etc. displayed in coffee posts.

Martín-Barbero Jesus's popular example of the transformation from profane to sacred comes from advertisements: "[...] simple activities such as washing, scrubbing, cleaning, and ironing have been transformed, become poets, and somehow become transcendent. Just think of how advertising makes a bottle of Coca-Cola a magical source of energy, wisdom and beauty - a source of life and youth itself" (Martín-Barbero, 1997). Similarly, the private/amateur coverage of coffee and coffee consumption on social media is increased. In these images, the act of drinking coffee becomes a rite that can create islands of peace and happiness almost anywhere. At the same time, the themes are closely related to wisdom and love.

In fact, this kind of reading of posts about coffee is made possible by ritual communication, which is based on the unified vision and emotional world of the community. It creates a symbol system in which trends, relationships, and models can be recognized. 


\section{What Do We Share on Social Media?}

Manovich divides the photos we post into three groups: casual, professional, and design photos (Manovich, 2017). However, Csilla Sebestyén and Zoltán Dragon warn that "within these, of course, a relatively large variance is possible based on the social, cultural, and aesthetic values of the users, which also have local and demographic aspects" (Dragon, 2018: 206).

Serafinelli (2018) highlights the peculiarities of the images. According to her, visual messages pass through different places. Photographs are taken in one place and appear in another. They are very easy to record and send; their value or significance often varies between time and platforms. In this case, meanings are limited by a number of socio-cultural contexts. These social and cultural environments need to be identified in order to learn more about the background of this habit. It is essential to know the environment in the online world in order to be able to recognize and adapt interpretations - just like in society, Serafinelli says, with different cultural contexts and tools of objects that can modify what they mean. In analysing the photo-sharing practices of the participants in the research, she realized that photographs cannot be seen as evidence of "who", "where", and "what" are part of reality but as evidence of bias, an ideologically captured interpretation of how the creators or decision makers have perceived and rebuilt reality (Serafinelli, 2018). The photos provide us several meanings intentionally yet not directly. "The use of the Internet, social media platforms, and smart mobile devices is leading to drastic changes in social habits. The growing practice of online photo sharing is changing traditional approaches to and about photography. Nowadays, photographs reveal the unclear contrast between real life and mediatized life" (Gefter, 2006). According to Alise Tifentale:

Competitive photography has always been communal, social in nature. Photographs exhibited or published in books were openly sponsored by other photographers. [...] This type of photography [...] closely follows the textbook prescriptions and conventions of a chosen pictorial paradigm. Or, in other words, the main criterion of competitive photography is likeability. In order for someone to take favorite pictures, they have to follow the rules. (Tifentale, 2016, qtd. in Dragon-Sebestyén, 2018: 205)

The rules mentioned above created a time for coffees pleasing to the eye. As a result, a class of postable and non-postable coffees emerged. A number of considerations determine when a coffee composition is spectacular enough to be published on Instagram. 


\section{Snapshot Culture}

Social media and smart mobile devices are targeting new forms of interactivity that combine the representative and communicative capabilities of images. As discussed, since their arrival, smart mobile devices have further enhanced the quantity and diversity of social forms of visuality (online communities, forums, social networking sites, etc.). Towards one of the most spectacular transformations of the traditional functions of photography: towards snapshot culture. (Chalfen, 1987)

Because of its visibility in online space, reality is not perceived by posters, which creates tensions in human relationships. In social media, people also feel that they cannot be present in the online and real world at the same time without losing their attention and care in one or the other. Perhaps under the fear of devaluation, we are moving towards the fast, snapshot sharing described by Chalfen.

\section{Method(ology)}

"You learn the [ethnographic] method, not what you start with", says Daniel Miller in his YouTube presentation. The ethnographic method can be transferred to the online space, but it is not an endless field, rather a new learning opportunity that helps to understand today's society. In my research, I follow the method of digital ethnography and the approach implicated by the method. ${ }^{2}$ I base my research on exploring what online representations are produced in the case of a pre-selected group and what cultural characteristics and social practices they refer to.

Daniel Miller mentions the benefits of digital anthropology in connection with the coronavirus epidemic, highlighting that people online share much more information with researchers than in real space. When someone visits their home, for example, they do not behave naturally: they get ready, they get ready for the reception, which is already an intervention in the field. However, the digital world liberates them, being less bound there by the interpersonal norms of the real world. In his view, anyone who interprets online and offline participation in cultural anthropology as two completely separate fields is not doing the right thing. If we do offline research based on different cases,

2 My interest in the ethnographic methods is based on an article by András Vajda, which analysed the Facebook activity of a local poet (who is also a teacher, journalist, and local historian), following issues like: what kinds of routines characterize the individual within the new media context and what cultural patterns influence these activities? See: Vajda, 2017. 
interpretations, why would it be different online? (Miller, 2020). ${ }^{3}$ Individuals' identities are projections of societies based on different socio-cultural characteristics as well as our online identity using the concept of Katalin Fehér (2015). So, if in real spaces individuals are able to become imprints of the cultural characteristics of society, this also applies to them in the online space. The digital world shows an expanded horizon, but - as I mentioned above - it is not an endless field since, just as physical research produces many different contexts, it is no different in the online space. At the beginning of my research, I wanted to explore the data through participatory observation, which is also important in the online space. This is not a series of independent interviews whose data can be compared to content found on the Internet. Participatory observation is an "evocative method" (Boellstorff, 2018: 188) which assumes that culture is in the human, and if someone is able to convey information about it, s/he allows the researcher to gain insight into his or her world of thought. In this case, the observed persons belong to a pre-defined group into which they are classified on the basis of their social cultural data. In my case, the research population consists of participants in the 20-24 age-group from Târgu-Mureş. Looking at Instagram as my number one field, I aim to reflect on a community whose behaviour is comparable both in online and in realistic (geographically limited) spaces. In their study, Krisztina Dörnyei and Ariel Mitev describe social media as a field. According to them, this field is:

A community structure consisting of relationships between individuals or organizations, which include social relationships between participants, and information about themselves. There are variations based on leisure or professional information. In addition to connections, they are also a means of self-expression for users; with different applications and content uploading, they can make their profiles unique and can communicate what they want to say. (Dörnyei-Mitev, 2010: 58)

Preparations before the pandemic showed participant observation and personal encounter as suitable research methods. However, due to the Covid-19 epidemic, my method has slightly changed: online observation and conversations became feasible. In the light of these changes, I have placed more focus on online representations. I use a new method known to me from the writings of Vincze Dalma, which is the mixed method of photomontage and semi-structured interview (in my case, partly participatory observation, partly semi-structured interview) (Vincze, 2019). The photomontage technique, also known as the

3 Miller, D. (2020). How to Conduct an Ethnography during Social Isolation. https://www.youtube. $\mathrm{com} /$ watch?v=NSiTrYB-0so\&t=241s. Further methodological reports on digital ethnography: Fuchs, 2020; Hine, 2015; Madianou-Miller, 2012; Mason, 2011. 
collage method, is a method used in new wave marketing research. Horváth and Mitev point out that this method may be suitable for exploring content (such as instinctive dimensions of self-representations) that is built up from memories and unquestionable content (for example: it can be used to evoke the motivations and effects behind coffee making and coffee-related posts). Collages can successfully bring emotions and background information to the surface (Horváth-Mitev, 2015).

Another important advantage of this method is that the production and use of such edited content - such as clips, short commercials, or the possibilities offered by Web 2.0 applications (Instagram) - is very typical of the young agegroup I have studied as well. Instagram is characterized by collage; the profiles function as large montages. "An individual profile created on social media sites is also a 'montage' of many, many images taken together. The total images can be considered as self-representations" (Vincze, 2019: 59). Pictures of coffee published on Instagram also tell stories about us and represent us. What others read from these is also a very exciting question, but, from the point of view of my research, what is very important is what self-reflexive process they initiate and, as a result, what Instagramers say about themselves and the motivations of their coffee-based posts based on my montages.

Why do I find the young adult group relevant for researching coffee online? This age-group is affected in several ways by coffee and its display on Instagram. Users of social media are primarily young people, members of Generation Z, who are active on social media for up to 10-12 hours a day (Guld-Maksa, 2015; Tókés-Velicu, 2015), and this produces a lot of created/shared content. The whole concept of Instagram was invented for them.

Today's young people are members of a generation that grows up on the Internet and knows its visual and linguistic world. This means they handle short, pictorial, up-to-date, truly real-time information. This agegroup is characterized by "brief attention"; therefore, most of the messages addressed to them should be structured on the basis of the principle of "less is more"; simplification and focus on the essence lead to results. (Törőcsik et al., 2019: 6)

The research of the worldviews and motivations behind the posts was carried out in a micro-community meeting these criteria: among Hungarian students living in the Transylvanian urban environment.

In terms of research, important motivations and attitudes emerged from Generation Z members' coffee posts. In the course of their analysis, generational characteristics and their behavioural patterns have come to the surface, which explain the motivations to create coffee posts nowadays. The transformation of coffee into a consumer article has initiated serious economic and cultural processes 
in modern societies. In the list of the most valuable brands in the world compiled by Forbes, coffee brands (Nescafé, Starbucks) are in the $34^{\text {th }}$ and $37^{\text {th }}$ places. ${ }^{4}$

The spread of coffee and the increase in its economic role can be well traced, but what are the social effects? I have mentioned above that coffee is universal in its own way - every nation drinks coffee and makes coffee a little differently. However, as in many other sectors, the symbolic social practices associated with coffee are globalizing due to the spread of media, network systems, and the Internet. Many formerly local, national coffee-making and consumption practices are becoming popular around the world, and fixed forms of coffee are spreading on online platforms (e.g. dalgona coffee).

\section{Summary. What Do Coffee Posts Say?}

Coffee houses were the arenas of civil society, and coffee can be interpreted as a pledge and means (also) of participation in public reasoning (Habermas, 1999). Instagram's coffee communities remind us of the semi-democratized world of cafés (Gyányi, 1996). Instagram gives almost anyone (provided they have the right tools, Internet access, and knowledge to use it) the opportunity to access this online public space after registration. In this sense, Instagram is the street where - just as the gates of coffee houses were only open to citizens - new coffee houses, more precisely, coffee communities are being created. This coffee community reproduces itself.

Who can be part of the online coffee community? As in traditional coffee house culture, no one is admitted here, only individuals who know and recognize the rites, symbols, and norms of the community, based on which the community as a system decides and filters who can be part of the community and who can become dominant within the community. The rules of community-building (community organizing and maintaining communication) are the way a given generation communicates. To gain membership and increase status within the community: you need to respond, comment, and reproduce if you want to become a recognized member. As in the offline space, social media has the characteristics and rules of age-appropriate and platform-related social construction communication that play a decisive role. Coffee is also important in building social networks and connections. We do not have coffee with anyone. Our roles, which we express during contact/conversations, change during coffee. Our attitude and behaviour towards our partner change when our relationship with the person reaches a level where we have coffee together. The act of drinking coffee creates a familiar, intimate environment and atmosphere that can be interpreted as a rite, which

4 Forbes's annual list of The World's Most Valuable Brands: Retrieved on: 29 September 2020, from: https://www.forbes.com/the-worlds-most-valuable-brands/\#3323e9be119c. 
can have a positive effect not only on friendly but also on formal (e.g. workplace) collaborations. Traditionally, a series of community experiences and interpersonal communication acts have been built around coffee. The need for these has not disappeared with the advent of digital interfaces either; we are not only looking for an audience but a community.

As in the physical world, the individual demands and searches - as many times as possible - create situations in the online space through which one can interact with other individuals. Coffee has an important role to play in both overcoming loneliness and fostering interpersonal relationships. It can be the perfect "excuse" to talk to others, and this feature is also available online. At the same time, not only the structure of the coffee communities but also the network of each individual is outlined along the likes and comments given to each coffee post. Since it has become available, coffee has lost its interpretation as a status symbol. However, in coffee posts, there are also objects that carry an underlying message. They seek to convey the sacredness of the coffee moment, prosperity, happiness, and young adult status. In the course of my research, it has become apparent that communication situations based on a mature symbol system are hidden in the background of coffee posts.

Interactions at the level of coffee posts are not just for aesthetic purposes, but they convey an important message between members of the online community. The notion of the "perfect image" much mentioned in the conversations points to an essential feature of the coffee community: manipulation is accepted and even expected here. It is necessary to edit and retouch the images to create something beautiful for the community. At the same time, coffee posts are also constructed in terms of content.

Generation Z members, according to research, clearly do not consume \# coffee content with those they are physically close to each other and could even do so by having regular coffee together. Many times, it is precisely the frustration that arises from their posts that (due to lack of time, distance, etc.) they cannot come into contact with the people with whom they would definitely like to share this moment. However, they also feel important to support each other with their reactions to those who only meet based on searching for \# coffee or feed filters. These rites are key elements because they are used by the "lonely" generation to satisfy their social needs. The coffee post can also be seen as a compensatory practice for the desire for physical connections online (see Marquard, 2001). Compensation is considered to be one of the most important motivations behind the coffee posts. This motivation takes the concept of parasocial relations to a new level as it is no longer limited to individuals we consider celebrities, but it also allows us to make parasocial interactions with any person who is not close to us physically but virtually. From a gender perspective, coffee posts are important for the messaging channel of both sexes; however, in terms of the content of 
their messages and the tendency of content organization, quite a lot of gender characteristics can be observed. While boys articulate a more informative, clearer message, girls are more likely to articulate their messages in an emotionally overheated or contemplative mood. Manipulation-based messaging as a procedure can be observed for both sexes, while a more marked difference can be observed in the numbers of variation in the produced content. In the context of the pandemic situation, the case of posting dalgona coffee (coffee consumption and coffee representation) also points to the previously mentioned globalizing trend of coffee culture. During the epidemic, Seoul, more precisely Dalgona in the South Korean region, will become a central player in the visual coffee narratives expressed in the online space. The region, which is the pinnacle of digital development and literacy as well as with regard to the number of cafés per capita, is also becoming the creator of mainstream forms of online coffee. The dalgona challenge is already producing worldwide many reproductions, just as in Târgu-Mureş.

What do young people say with coffee posts? A regionally recognizable relationship between coffee and adulthood has been explored. The stories about their first coffee experience are clearly an act with the characteristics of an initiating rite. The initiates are already members of adult society.

The relationship between visuality and coffee. It should be noted that the Instagram generation prefers pictorial, short, and real-time information content. This has also been noticed by the marketing and advertising industries. Young people's coffee preferences are primarily based on the appearance of the coffee. At the same time, visual appearance is the aspect that determines postability. As for the community characteristics of coffee distribution, it is important to note that this community is also organized on the basis of common interest and reinforcement (sympathy and its expression). It is a well-known and recognized action among this age-group, which is a daily routine for them. However, there is also a kind of frustration in these actions; they feel that their interpersonal relationships in the real world decrease and the online presence is becoming more and more pronounced. The cure for this is the snapshot culture, the possibility of quick sharing although (as discussed above) these posts are mostly created through lengthy preparations. So, this procedure cannot completely resolve the discomfort of Generation Z either. Members of the coffee community produce content that meets the criteria of competitive photography (Tifentale, 2016) and community. And the common concept is likability as both competitive photography and communities are based on recognition and the system of criteria by which a given pictorial content can be recognized. At the basis of the criteria system, there are the message (which uses symbols to represent what adulthood means - happiness, well-being, etc.) and manipulation.

My final conclusion is that coffee posts are a means of expressing our identity. Based on Vincze's (2019: 59) statement that montages can be considered self- 
representations on Instagram, with the self-reflexive process (photomontage technique) I discovered that with the help of the posts users are able to convey to the world their characteristics and personality traits that determine their identity. Through coffee posts, self-branding (also) takes place.

\section{References}

Boellstorff T. (2018). A digitális antropológia újragondolása [Rethinking Digital Anthropology]. Replika 108-109(3-4): 173-192.

Chalfen, R. (1987). Snapshot Versions of Life. Bowling Green, OH: Bowling Green State University Popular Press, 119-157.

Cowan B. (2005). The Social Life of Coffee - The Emergence of the British Coffeehouse. New Haven-London: Yale University Press.

Dörnyei, K.-Mitev, A. (2010). Netnográfia avagy on-line karosszék-etnográfia a marketingkutatásban [Netnography or Online Armchair Ethnography in Marketing Research]. Vezetéstudomány 41(4).

Dragon, Z.-Sebestyén, Cs. (2018). \#BREW: influencer-kísérlet az Instagram újhullámos kávéközösségében [\#BREW: An Influencer Experiment in Instagram's New Wave Coffee Community]. Digitális Bölcsészet Múhely.

Durkheim, É. (2002). A vallási élet elemi formái: A totemisztikus rendszer Ausztráliában [Elementary Forms of Religious Life: The Totemistic System in Australia]. Budapest: L’Harmattan.

Fehér, K. (2015). Milyen stratégiák mentén épül fel a digitális identitás? Második feltáró kutatási szakasz: vállalatvezetők és döntéshozók [What Are the Strategies along Which Digital Identity Is Built? Second Exploratory Research Phase: Business Leaders and Decision Makers]. Médiakutató 16(2): 25-35. http://epa.niif.hu/03000/03056/00059/pdf/EPA03056_mediakutato_2015_ ny\%C3\%A1r_025-028.pdf (accessed on: 13.05.2020).

Fuchs, C. (2020). Everyday Life and Everyday Communication in Coronavirus. Capitalism Triple C: Communication, Capitalism \& Critique 18(1): 375-399.

Gefter, A. (2006). This Is Your Space. New Scientist 191: 46-48.

Guld, Á. (2020).Étkezőshow-k a YouTube-on. A mukbang videók népszerúségének hátteréről egy kvalitatív befogadásvizsgálat tükrében [Dining Shows on YouTube. On the Background of the Popularity of Mukbang Videos in the Light of a Qualitative Inclusion Study]. Marketing $\&$ Menedzsment 1. https://journals. lib.pte.hu/index.php/mm/article/view/3237/3038 (accessed on: 13.03.2020).

Guld, Á.-Maksa, Gy. (2015). Fiatalok kommunikációjának és médiahasználatának vizsgálata [Examination of Young People's Communication and Media Use]. In: Törőcsik, M. (ed.), A Z generáció magatartása és kommunikációja [Behaviour and Communication of the Generation Z]. Pécs: University of Pécs, 52-65. 
Gyáni, G. (1996). A kávéházba járó polgár [The Café-Goer Citizen]. Budapesti Negyed 4(2-3): 57-68. Retrieved on: 30 September 2020, from: https://epa. oszk.hu/00000/00003/00011/gyani.htm (accessed on: 23.09.2020).

Habermas, J.-Zoltán, E.-Zsuzsa, M. G.-Gábor, F. (1999). Structural Change in Social Publicity: Studies on a Category of Civil Society. Budapest: Osiris.

Hine, C. (2000). Virtual Ethnography. London: Sage.

(2015). Ethnography for the Internet: Embedded, Embodied and Every Day. London: Bloomsbury.

Kleidas, M.-Jolliffe, L. (2010). Coffee Attraction Experiences: A Narrative Study. Tourism: An International Interdisciplinary Journal 58(1): 61-73. Retrieved on: 30 September 2020, from: https://hrcak.srce.hr/56112 (accessed on: 24.09.2020).

Madianou, M.-Miller, D. (2012). Migration and New Media: Transnational Families and Polymedia. London: Routledge.

Manovich, L. (2017). Instagram and Contemporary Image. http://manovich. net/index.php/projects/instagram-and-contemporary-image (accessed on: 09.02.2020).

Martín-Barbero, J. (1997). Mass Media as a Site of Resacralization of Contemporary Cultures. In: Hoover, Stewart-Lundby, Knut (eds.), Rethinking Media, Religion and Culture. London: Sage, 102-116.

Mason, J. (2011). Facet Methodology: The Case for an Inventive Research Orientation. Methodological Innovations Online 6(3): 75-92.

Miller, D. (2018). Közösségi oldalak [Community Sites]. Replika 108-109(3-4): 157-172.

Rheingold, H. (1993). The Virtual Community. http://www.rheingold.com/vc/ book/ (accessed on: 30.03.2020).

Serafinelli, E. (2018). Digital Life on Instagram: New Social Communication of Photography. Emerald Group Publishing.

Tifentale, A. (2016). Defining Competitive Photography. http://www.alisetifentale. net/research-blog-at/2016/1/17/work-in-progress-defining-competitivephotography (accessed on: 24.02.2020).

Tókés, Gy. E.-Velicu, A. (2015). Poveştile de dincolo de statistici: despre competențele digitale ale copiilor şi adolescenților din România [Tales beyond Statistics: About the Digital Competences of Children and Teenagers in Romania]. Revista Română de Sociologie 4: 431-458.

Törőcsik, M.-Szűcs, K.-Kehl, D. (2019). Generációs gondolkodás - A Z és az Y generáció életstílus csoportjai [Generational Thinking - Lifestyle Groups of the Z and Y Generations]. Marketing \& Menedzsement 48(2): 3-15. https:// journals.lib.pte.hu/index.php/mm/article/view/861 (accessed on: 14.05.2020).

Turner, V. W. (1969). The Ritual Process: Structure and Anti-Structure. Chicago: Aldine. 
Ujhelyi, A. (2011). Online csoportok kívülről és belülről. Az Internetes közösségek szociálpszichológiai vizsgálata [Online Groups from the Outside and the Inside. Socio-Psychological Study of Internet Communities]. Oktatás-Informatika 3-4. http://www.eltereader.hu/media/2013/05/Okt_Inf_2011_3_4_opt.pdf\#page=4 (accessed on: 14.04.2020).

Ukers, W. H. (1922). All about Coffee. New York: The Tea and Coffee Trade Journal Company. Retrieved on: 23 March 2020, from: https://www.gutenberg. org/files/28500/28500-h/28500-h.htm (accessed on: 23.03.2020).

Vajda, A. (2017). Alkalmi költészet és közösségi média. A populáris írásbeliség változó mediális környezetei [Occasional Poetry and Social Media. Changing Media Contexts of Popular Literacy]. In: Jakab, Albert Zsolt-Vajda, András (eds.), Aranyhíd. Tanulmányok Keszeg Vilmos tiszteletére [Golden Gate. Papers in Honour of Vilmos Keszeg]. Cluj-Napoca: KJNT-BBTE Magyar Néprajz és Antropológia Intézet-Erdélyi Múzeum-Egyesület, 927-946.

Varga, V.-Dúll, Andrea. (2001). „Kávéház, te vagy a hazám, s immár egyetlen otthonom”. Budapest kávéházai a századfordulón - környezetpszichológiai megközelítésben ["Café, You Are My Country, and Now My Only Home”. Budapest Cafés at the Turn of the Century - An Environmental Psychological Approach]. Magyar Pszichológiai Szemle [Hungarian Psychological Review] 56(4): 557-592.

\section{Cite as:}

Csáki, Cs. (2020). The Initiators of Our Everyday Life - Relationship between Coffee and Instagram. Acta Universitatis Sapientiae, Communicatio 7: 157170. DOI: 10.2478/auscom-2020-0011. 